\title{
THE EFFECT OF MANAGEMENT COMMITMENT TO SERVICE QUALITY ON JOB EMBEDDEDNESS AND PERFORMANCE OUTCOMES
}

\author{
Osman M. Karatepe ${ }^{1}$, Georgiana Karadas ${ }^{2}$ \\ ${ }^{1,2}$ Faculty of Tourism, Eastern Mediterranean University, \\ Gazimagusa, TRNC, via Mersin 10, Turkey \\ E-mails: ${ }^{1}$ osman.karatepe@emu.edu.tr (corresponding author); \\ ${ }^{2}$ georgiana.karadas@emu.edu.tr
}

Received 24 March 2011; accepted 29 June 2011

\begin{abstract}
The purpose of this study is to develop and test a conceptual model that examines job embeddedness as a partial mediator of the impact of management commitment to service quality on service recovery performance and extra-role customer service. Training, empowerment, and rewards are regarded as the three important indicators of management commitment to service quality. Data were obtained from a sample of fulltime frontline hotel employees with a time lag of one week in Romania. The results reveal that training, empowerment, and rewards are positively related to job embeddedness. As hypothesized, empowerment, rewards, and job embeddedness enhance service recovery performance, while training and empowerment increase extra-role customer service. The results further demonstrate that job embeddedness acts as a partial mediator of the effects of empowerment and rewards on service recovery performance. Implications of the results are discussed and future research directions are offered.
\end{abstract}

Keywords: commitment to service quality, extra-role customer service, job embeddedness, Romania, service recovery performance.

Reference to this paper should be made as follows: Karatepe, O. M.; Karadas, G. 2012. The effect of management commitment to service quality on job embeddedness and performance outcomes, Journal of Business Economics and Management 13(4): 614-636.

JEL Classification: M3-Marketing and Advertising, M31-Marketing.

\section{Introduction}

In a turbulent business environment of scarce resources, intensifying competition and rapid rates of technological change, it is widely acknowledged among researchers and practitioners that delivery of service quality leads to retention of satisfied and loyal customers. Because of their boundary-spanning roles, frontline employees having intense face-to-face or voice-to-voice interactions with customers play a critical role in delivery of service quality and effective service recovery (Gil et al. 2006; Hartline, Ferrell 1996; Min, H., Min, H. 2005; Yavas et al. 2004). Despite this realization, low pay, 
long work hours, heavy workloads, customer aggression, role stress, and inconvenient work schedules are among the problems facing these employees (e.g. Babakus et al. 2008; Karatepe et al. 2008; Miller, Madsen 2003; Solnet, Hood 2008). Under these circumstances, managers have difficulty retaining skilled and high performing employees.

Job embeddedness that refers to "the combined forces that keep a person from leaving his or her job" (Yao et al. 2004: 159) appears to be a potential remedy for retention of such employees. That is, employees can be embedded in their job through various organizational and community-related forces (Crossley et al. 2007). Training, empowerment, and rewards are considered to be among the significant indicators of management commitment to service quality (Babakus et al. 2003). These human resource practices are among Pfeffer's (1994) list of best human resource practices. Human resource practices that increase performance are known as high-performance work practices (HPWPs) (Combs et al. 2006). These practices (e.g. training and development and flexible work arrangements) increase employees' knowledge, skills, and abilities, empower them to use these knowledge, skills, and abilities, and motivate them through rewards and internal promotions to do so (Combs et al. 2006). Therefore, the presence of such practices seems to enhance employees' job embeddedness. An examination of the relevant literature also reveals that the availability of training, empowerment, and rewards in the workplace elucidates top management's commitment to service quality (Babakus et al. 2003) and results in high quality performance (Boshoff, Allen 2000; Yavas et al. 2010). These employees are also embedded in their job and perform effectively (Holtom et al. 2006; Lee et al. 2004).

\section{Purpose}

Against this backdrop, the purpose of this study is to develop and test a conceptual model that investigates job embeddedness as a partial mediator of the effect of management commitment to service quality on service recovery performance and extra-role customer service. That is, job embeddedness is treated as a partial mediator of the impacts of training, empowerment, and rewards on the abovementioned performance outcomes.

This study makes several useful contributions to the services marketing literature. Specifically, there is a dearth of empirical research concerning factors intensifying employees' job embeddedness (cf. Bergiel et al. 2009). As cogently discussed by Babakus et al. (2003), training will produce the intended outcomes provided that empowerment and rewards are in place. Likewise, empowerment will lead to the intended outcomes provided that it is used in combination with appropriate training and rewards. These HPWPs reinforce and support each other when they are used in a coordinated way (Combs et al. 2006). This is also consistent with internal fit that "their collective effect will be greater than the sum of their individual parts" (Wall, Wood 2005: 431). As discussed by Guest et al. (2004), internally consistent human resource practices or HPWPs reflect the organizational logic. Therefore, it is important to have an understanding of the effects of training, empowerment, and rewards as the indicators of management commitment to service quality or internally consistent HPWPs on employees' job embeddedness in frontline service jobs. 
As an anti-withdrawal construct, job embeddedness has been reported to reduce employees' turnover intentions and voluntary turnover (e.g. Bergiel et al. 2009; Lee et al. 2004; Mitchell et al. 2001). However, the relationship between job embeddedness and performance outcomes has not received much empirical attention in the relevant literature (cf. Halbesleben, Wheeler 2008; Sekiguchi et al. 2008). Service recovery performance and extra-role customer service are the two performance outcomes of frontline employees examined in this study. There are at least two reasons for selecting such performance outcomes. First, service recovery performance refers to frontline employees' abilities and actions to resolve a service failure to the satisfaction of the customer (Babakus et al. 2003). There are a number of customers' requests and complaints frontline employees have to deal with. Therefore, frontline employees should demonstrate effective service recovery efforts in order to return aggrieved customers to a state of satisfaction after a service failure (Boshoff, Allen 2000; Yavas et al. 2004). Second, extra-role customer service is defined as "discretionary behaviors of contact employees in serving customers that extend beyond formal role requirements" (Bettencourt, Brown 1997: 41). Effective service recovery efforts require a pool of employees who can adapt their abilities to the specific complaint situation and display proactive behaviors (De Jong, De Ruyter 2004). With this recognition, service recovery performance can be considered a part of extra-role customer service or extra-role performance (cf. Sekiguchi et al. 2008). Consequently, this study tests job embeddedness as a partial mediator of the impacts of training, empowerment, and rewards on service recovery performance and extra-role customer service based on data obtained from frontline hotel employees with a oneweek time lag in Romania.

Finally, the results of this empirical investigation may prove useful from a managerial perspective concerning the relationships among the indicators of management commitment to service quality, job embeddedness, and performance outcomes. The next section of the article provides the theoretical underpinnings, hypotheses, and conceptual model. Then, the article delineates discussions of the method and findings of the empirical study conducted with frontline hotel employees in Romania. The article concludes with implications of the results and future research directions.

\section{Theoretical underpinnings, hypotheses, and conceptual model}

\subsection{Background}

Frontline employees working in an environment where management is not committed to service excellence cannot deal with customers' requests and complaints successfully. It is obvious that any efforts made by such employees are doomed to failure from the start unless management is fully committed to service excellence (Zemke 1991). Since frontline employees have a crucial role in service delivery process, managements of the service firms should consider them strategic partners in delivery of service quality and retention of satisfied and loyal customers. However, mistakes and failures in service delivery are inevitable. Therefore, service providers should "do things very right the second time" (De Ruyter, Wetzels 2000: 91). Otherwise, service failures lead to a 
number of detrimental outcomes (for example, customer dissatisfaction, negative wordof-mouth, and decreases in repurchase behaviors) (Davidow 2003).

As argued by Forrester (2000), management desires and good intentions do not mean much if employees do not perceive them as such. Therefore, management commitment to service quality should be defined from the frontline employee's perspective. Management commitment to service quality refers to “employees' appraisal of an organization's commitment to nurture, develop, support, and reward its employees to achieve service excellence" (Babakus et al. 2003: 275). A close examination of the services marketing literature delineates a number of potential indicators of management commitment to service quality (for example, training, empowerment, rewards, service technology, perceived organizational support, recruitment and selection, and servant leadership) (Ashill et al. 2008; Babakus et al. 2003; Kim et al. 2009; Schneider et al. 1998). Consistent with the work of Babakus et al. (2003) and Pfeffer's (1994) list of best human resource practices, training, empowerment, and rewards are considered to be the significant indicators of management commitment to service quality in this study. According to Boselie et al.'s study (2005) focusing on the linkage between human resource management and performance, training and development, contingent pay and rewards, and direct participation such as empowerment and employee involvement are in the top six human resource practices. In addition, training, empowerment, and rewards have been reported or discussed to increase organizational development, attract qualified individuals, and enhance employee work outcomes (e.g. organizational commitment, job performance, and job satisfaction) (Ashill et al. 2005; Marković 2008; Rees, Althakhri 2008; Singh 2007; Yavas et al. 2010).

The AMO (ability motivation, and opportunity) model also provides support for the relationships between HPWPs and performance outcomes. Specifically, the AMO model focuses on the importance of variables at the individual level pertaining to employees' skills and competences, their motivation, and their opportunity to participate (Paauwe 2009). Employees perform better when they receive training to increase their knowledge and abilities, have the motivations and opportunities to contribute (Boxall, Macky 2009). That is, employees increase their knowledge and abilities via training programs, are motivated through rewards, and have the opportunity to deal with customers' requests and complaints effectively via empowerment.

The indicators of management commitment to service quality or HPWPs should also enhance employees' job embeddedness. Links, fit, and sacrifice are the three dimensions of job embeddedness. Links refer to "formal or informal connections between a person and institutions or other people", while fit refers to "an employee's perceived compatibility or comfort with an organization and with his or her environment" (Mitchell et al. 2001: 1105). In Mitchell et al.'s (2001) study, sacrifice is defined as "the perceived cost of material or psychological benefits that may be forfeited by leaving a job". Employees would be job embedded or socially enmeshed in the organization as the number of these links increase. When employees find that there is fit between their goals and values and those of the organization and the community, they would have higher job embeddedness. Finally, employees perceiving that there are a number of costs associated with 
leaving the organization would also have elevated levels of job embeddedness. Research indeed demonstrates that job embeddedness reduces turnover intentions and voluntary turnover and enhances job and extra-role performances (Lee et al. 2004).

\subsection{Hypotheses}

\subsubsection{Management commitment to service quality and job embeddedness}

Training, empowerment, and rewards are the three important indicators of management commitment to service quality increasing employees' job embeddedness. Training employees on a continuous basis is important, because training would make employees become acquainted with their job-related tasks and organizational values and beliefs (Kusluvan et al. 2010). However, employees who are devoid of the requisite job and interpersonal skills are incapable of providing quality services and resolving customers' complaints effectively (Boshoff, Allen 2000). With this realization, employees' inability to respond to service failures can be remedied by training and development (Babakus et al. 2003). That is, frontline employees are in need of basic skills training focusing on delivery of service quality and effective service recovery (cf. Hoque 1999). Empirically, it has been reported that training increases job embeddedness among employees of a state department of corrections (Bergiel et al. 2009).

Empowerment refers to "the freedom and ability to make decisions and commitments" (Forrester 2000: 67). Frontline employees should be empowered, because they are expected to deal with customers' requests and complaints, and "the exact tasks required to improve customer satisfaction cannot be prespecified" (Banker et al. 1996: 923). Otherwise, frontline employees who lack the authority and responsibility to act and react are unable to handle complaints (Lewis, Gabrielsen 1998). The presence of empowerment practices in the workplace motivates employees and creates a sense of attachment to the organization (Babakus et al. 2003; Bowen, Lawler 1995).

Having appropriate reward policies in place is important for frontline service jobs, which are generally low-paying positions (Babakus et al. 2003). The availability of proper levels of pay and other types of rewards for exemplary service efforts in the organization demonstrates top management's commitment to service quality (Ashill et al. 2005). As a result, employees would be embedded in their job when they are rewarded for their efforts. In empirical terms, compensation has been reported to depict a positive association with job embeddedness (Bergiel et al. 2009). Consequently, empowerment programs can fail without proper training and rewards. Similarly, training programs will also fail if frontline employees are not empowered and rewarded. The abovementioned information is consistent with internal fit. Internal fit contends that the joint presence of HPWPs creates synergy (Wall, Wood 2005). Under these circumstances, the joint presence of training, empowerment, and rewards would be a powerful signal for retaining employees in the organization. Accordingly, the following hypotheses are proposed:

H1(a): Training is positively related to frontline employees' job embeddedness.

H1(b): Empowerment is positively related to frontline employees' job embeddedness.

H1(c): Rewards are positively related to frontline employees' job embeddedness. 


\subsubsection{Management commitment to service quality and performance outcomes}

Employees can effectively recover from service failures if they are trained in listening and problem-solving skills as well as technical skills (cf. Boshoff, Allen 2000; Yavas et al. 2010). Empowered employees would be able to provide quick, appropriate, and equitable responses to complainants (Boshoff, Allen 2000; Yavas et al. 2003). The presence of appropriate reward policies in the workplace encourages trained and empowered employees to provide service excellence and resolve customers' complaints effectively (Ashill et al. 2005; Yavas et al. 2003). This is in parallel with the AMO framework (Boxall, Macky 2009). Such employees would also go beyond their formal role requirements to help customers and make them satisfied. This makes sense, because employees can display discretionary behaviors to resolve complaints according to customers' expectations. Therefore, it is important to investigate the relative effects of HPWPs (e.g. training, empowerment, and performance-related pay) on performance (Wall, Wood 2005).

In empirical terms, Boshoff and Allen (2000) demonstrated that empowerment and rewards positively affected frontline bank employees' service recovery performance in South Africa. In another empirical study conducted with frontline employees in the private sector hospitals in New Zealand, Ashill et al. (2004) reported similar findings. Yavas et al. (2003) reported that empowerment positively influenced frontline bank employees' service recovery performance in Turkey. Recently, Yavas et al. (2010) also indicated that training and empowerment triggered frontline employees' service recovery performance in Turkish hotels. Accordingly, the following hypotheses are proposed:

H2: Training is positively related to frontline employees' (a) service recovery performance and (b) extra-role customer service.

H3: Empowerment is positively related to frontline employees' (a) service recovery performance and (b) extra-role customer service.

H4: Rewards are positively related to frontline employees' (a) service recovery performance and (b) extra-role customer service.

\subsubsection{Job embeddedness and performance outcomes}

According to job embeddedness theory, employees having a number of links and a good fit with the organization and the job are motivated to display good performance (Lee et al. 2004). This is also valid for employees who sacrifice valued things as a result of leaving the organization (Lee et al. 2004). This is not surprising, because such employees would have the opportunity to demonstrate their skills to deliver quality services and deal with disgruntled customers successfully. However, there is limited empirical evidence demonstrating the impact of job embeddedness on performance outcomes. Specifically, Lee et al. (2004) reported that on-the-job embeddedness increased job performance and organizational citizenship behavior among employees of a large international financial organization. It was found that job embeddedness enhanced self-rated and coworker-rated performances among working adults (Halbesleben, Wheeler 2008). Recently, in a study of frontline hotel employees in Cameroon, Karatepe and Ngeche 
(2012) demonstrated that job embeddedness was positively related to job performance. Therefore, the following hypotheses are proposed:

H5: Job embeddedness is positively related to frontline employees' (a) service recovery performance and (b) extra-role customer service.

\subsubsection{Job embeddednes as a partial mediator}

The hypothesized relationships given above explicitly refer to the partial mediating role of job embeddedness. As indicated before, job embeddedness theory contends that links, fit, and sacrifice are the three components of job embeddedness that enable the organizations to retain employees and that make employees display high quality performance in the workplace. Specifically, employees having formal or informal connections with their coworkers and friends in the organization have low levels of turnover intentions and are motivated to display positive performance outcomes. Having fit with the job and the organization as well as the environment is important for such employees to remain in the organization and have high quality performance in the workplace. Employees recognize that they will sacrifice or lose a number of benefits as a result of leaving the organization. Under these circumstances, employees who are embedded in the job will have effective performance outcomes. Employees who are trained, empowered, and rewarded would be embedded in the job and display effective service recovery performance. These employees would also go beyond their formal job-related responsibilities to make customers satisfied.

Consequently, training, empowerment, and rewards influence service recovery performance and extra-role customer service directly and indirectly through job embeddedness. Therefore, the following hypotheses are proposed:

H6: Job embeddedness partially mediates the effects of (a) training, (b) empowerment, and (c) rewards on frontline employees' service recovery performance.

H7: Job embeddedness partially mediates the effects of (a) training, (b) empowerment, and (c) rewards on frontline employees' extra-role customer service.

\subsection{Conceptual model}

The conceptual model is presented in Figure 1. According to the conceptual model, training, empowerment, and rewards enhance frontline employees' job embeddedness,

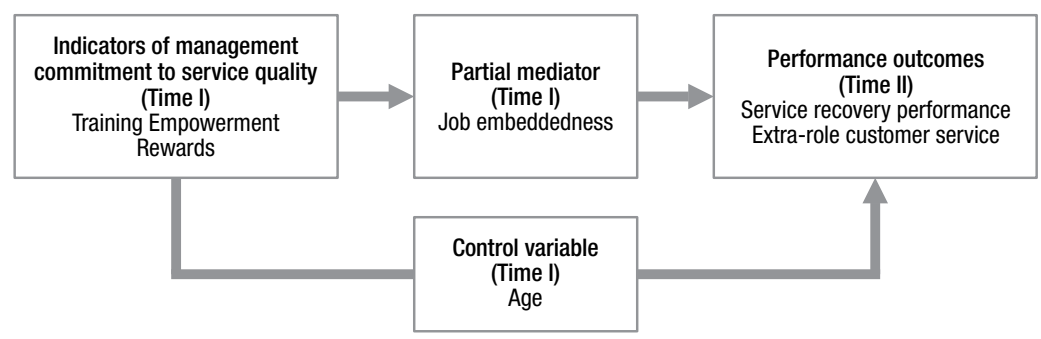

Fig. 1. Conceptual model 
service recovery performance, and extra-role customer service. The model also contends that job embeddedness increases the abovementioned performance outcomes. Finally, the model posits that job embeddedness acts as a partial mediator of the effects of training, empowerment, and rewards on service recovery performance and extra-role customer service. In the model age is treated as a control variable (e.g. Halbesleben, Wheeler 2008).

\section{Method}

\subsection{Sample and procedure}

Data were collected from a sample of full-time frontline employees in the four- and fivestar hotels in the Poiana Brasov region in Romania. This region is one of the most important winter tourist destinations in the country. These frontline employees (e.g. front desk agents, food servers, bartenders, door attendants, guest relations representatives, and bell attendants) had intense face-to-face or voice-to-voice contact with customers and spent most of their time dealing with customers' requests and complaints.

There were 7 four-star hotels and only 1 five-star hotel in the Poiana Brasov region at the time of this study. Managements of these hotels were contacted using a letter that demonstrated the objectives of the empirical study and request for permission for data collection. Managements of all hotels agreed to participate in this empirical study. However, they did not allow the researcher to directly contact their frontline employees. Therefore, hotel managers distributed the questionnaires to their frontline employees. The first page of each questionnaire consisted of information about the assurance of anonymity and confidentiality. Each frontline employee self-administered the time I questionnaire, sealed it in an envelope, and placed it in a special box. Then, the researcher collected the time I questionnaires from this box. The same procedure was also used for the time II questionnaires.

Podsakoff et al. (2003: 885) state, “...common method biases arise from having a common rater, a common measurement context, a common item context, or from the characteristics of the items themselves." Therefore, consistent with the suggestions made by Podsakoff et al. (2003), this study used a temporal separation between the measurement of the predictor and criterion variables. Such a data collection practice was deemed necessary for minimizing the possibility of common method bias. Specifically, data were obtained from frontline employees with a one-week time lag. Using one-week time lag is also consistent with that of Haar (2004) and appears to be appropriate for small sample sizes and minimization of respondent attrition. The time I questionnaire consisted of the training, empowerment, rewards, and job embeddedness measures as well as items concerning respondents' profile. The time II questionnaire included the service recovery performance and extra-customer service measures. Frontline employees who responded at time I were also requested to participate in the study at time II. By paying utmost attention to the issue of confidentiality, the researcher prepared a master list containing the name of each frontline employee in the hotel. Each employee in this master list had an identification number. An identification number was also written on each question- 
naire. This procedure was used at both time I and time II data collection stages so that the questionnaires at time I and time II could be matched.

123 questionnaires were distributed to frontline employees at time I. By the cut-off date for data collection, 114 questionnaires were retrieved. However, 4 questionnaires were eliminated due to the missing information. Usable 110 questionnaires were retrieved, yielding a response rate of $89.4 \%$. 110 time II questionnaires were then distributed to the same frontline employees. All frontline employees participated in the second stage of this study. Therefore, 110 usable questionnaires were returned, which yielded a response rate of $100 \%$ of the second sample (time II) and a response rate of $89.4 \%$ of the first sample (time I).

$37 \%$ of the respondents were aged between 18 and 27 years and $39 \%$ were between the ages of 28-37. The rest were older than $37.58 \%$ of the respondents were male. $66 \%$ of the respondents had tenures of five years or less and the rest had been with their hotel for six or more years. $6 \%$ of the respondents had primary school education, while one-half of the respondents had secondary and high school education. $20 \%$ of the respondents had two-year college degrees and $18 \%$ four-year college degrees. The rest had graduate degrees.

\subsection{Measurement}

All constructs in the conceptual model were operationalized using the scale items derived from past writings in the relevant literature. Specifically, training (six items), rewards (five items), and service recovery performance (five items) were operationalized via items from Boshoff and Allen (2000). Five items adapted from Hayes (1994) were used to measure empowerment. Extra-role customer service was measured using five items from Bettencourt and Brown (1997). Items in training, empowerment, rewards, job embeddedness, service recovery performance, and extra-role customer service were rated on five-point scales ranging from 5 (strongly agree) to 1 (strongly disagree). One negatively worded item in job embeddedness was reverse scored. Higher scores indicated higher training, empowerment, rewards, job embeddedness, service recovery performance, and extra-role customer service. As a control variable, age was measured using a five-point scale. Higher scores showed older age.

All items were originally prepared in English and then translated into Romanian via the back-translation method (Parameswaran, Yaprak 1987). Specifically, the time I and time II questionnaires were prepared in English. Then, two bilingual individuals (fluent in both Romanian and English) participated independently in the translation process. Finally, the researcher further checked the two versions of the time I and time II questionnaires in English for any inconsistencies. In addition, the time I and time II questionnaires were tested with two different pilot samples of 10 frontline hotel employees. In light of the feedback obtained from hotel managers, frontline employees did not have any difficulty understanding items. Therefore, there was no compelling reason to make changes in the questionnaires. 


\subsection{Data analysis}

All measures were subjected to confirmatory factor analysis in order to evaluate the psychometric properties of the scale items in terms of convergent and discriminant validity (Fornell, Larcker 1981; Joreskog, Sorbom 1996). Internal consistency reliabilities were checked using the commonly accepted threshold of .70.

Hierarchical multiple regression analysis was employed to test the direct effects. Hierarchical multiple regression analysis was also employed to test the mediating effects in light of the guidelines provided by Baron and Kenny (1986). Such measurement and evaluation practices are consonant with other empirical studies (e.g. Han, Back 2006; Karatepe et al. 2010; Yagil et al. 2008).

In the analysis predicting job embeddedness, age was entered in step 1 and as the indicators of management commitment to service quality, training, empowerment, and rewards in step 2. Age was entered in step 1, training, empowerment, and rewards in step 2, and job embeddedness in step 3 in predicting service recovery performance. This procedure was applied to the other mediation analysis. Sobel test, which refers to "an approximate significance test for the indirect effect of the independent variable on the dependent variable via the mediator" (Baron, Kenny 1986: 1177), was also used to assess the significance of the mediating effects.

\section{Results}

\subsection{Measurement results}

The initial results of confirmatory factor analysis indicated that several items significantly loaded on more than one latent variable. Under these circumstances, six items with significant loadings were removed from subsequent analysis. As shown in Table 1, two items each from the training, empowerment, and service recovery performance measures were dropped. The final results of confirmatory factor analysis demonstrated the following fit statistics: $\left(\chi^{2}=554.01, d f=309 ; \chi^{2} / \mathrm{df}=1.79\right.$; CFI [Comparative fit index $]=.92$; IFI [Incremental fit index] $=.92$; RMSEA [Root mean square error of approximation $]=.085$; SRMR [Standardized root mean square residual $]=.053$ ). The results showed a reasonable fit of the six-factor model to the data on the basis of a number of fit statistics.

Table 1 also presents the standardized loadings and their $t$-values as well as average variance extracted for each construct. Specifically, all standardized loadings were equal to or above .70 . The average variance extracted by the underlying latent variables ranged from .57 to .85 . The shared variances among the underlying latent variables were below each average variance extracted. Overall, the measures exhibited strong psychometric properties in terms of convergent and discriminant validity (Fornell, Larker 1981).

Composite scores for each measure were obtained by averaging scores across items representing that measure. Scale reliabilities, means, standard deviations, and correlations of study variables are given in Table 2. As also reported in Table 2, all coefficient alphas were above the commonly accepted threshold of .70. 
O. M. Karatepe, G. Karadas. The effect of management commitment to service quality on job embeddedness ...

Table 1. Scale items and confirmatory factor analysis results

\begin{tabular}{|c|c|c|c|}
\hline Scale items & $\begin{array}{l}\text { Standardized } \\
\text { loadings }\end{array}$ & $t$-value & $\mathrm{AVE}^{*}$ \\
\hline Training & & & .75 \\
\hline I receive continued training to provide good service & .79 & 9.68 & \\
\hline $\begin{array}{l}\text { I received extensive customer service training before } \\
\text { I came into contact with customers }\end{array}$ & $-{ }^{* *}$ & - & \\
\hline I receive training on how to serve customers better & .88 & 11.58 & \\
\hline $\begin{array}{l}\text { I receive training on how to deal with complaining } \\
\text { customers }\end{array}$ & .90 & 11.85 & \\
\hline I receive training on dealing with customer problems & .88 & 11.60 & \\
\hline I was trained to deal with customer complaints & $-^{* *}$ & - & \\
\hline Empowerment & & & .85 \\
\hline I am empowered to solve customer problems & $-^{* *}$ & - & \\
\hline $\begin{array}{l}\text { I am encouraged to handle customer problems } \\
\text { by myself }\end{array}$ & $--^{* *}$ & - & \\
\hline $\begin{array}{l}\text { I do not have to get management's approval before } \\
\text { I handle customer problem }\end{array}$ & .88 & 11.52 & \\
\hline $\begin{array}{l}\text { I am allowed to do almost anything to solve customer } \\
\text { problems }\end{array}$ & .92 & 12.45 & \\
\hline I have control over how I solve customer problems & .96 & 13.51 & \\
\hline Rewards & & & .77 \\
\hline $\begin{array}{l}\text { If I improve the level of service I offer customers, } \\
\text { I will be rewarded }\end{array}$ & .78 & 9.69 & \\
\hline $\begin{array}{l}\text { The rewards I receive are based on customer } \\
\text { evaluations of service }\end{array}$ & .87 & 11.31 & \\
\hline I am rewarded for serving customers well & .87 & 11.50 & \\
\hline $\begin{array}{l}\text { I am rewarded for dealing effectively with customer } \\
\text { problems }\end{array}$ & .95 & 13.34 & \\
\hline I am rewarded for satisfying complaining customers & .89 & 11.94 & \\
\hline Job embeddedness & & & .78 \\
\hline I feel attached to this hotel & .90 & 12.17 & \\
\hline It would be difficult for me to leave this hotel & .94 & 13.11 & \\
\hline I am too caught up in this hotel to leave & .91 & 12.37 & \\
\hline I feel tied to this hotel & .92 & 12.66 & \\
\hline I simply could not leave the hotel that I work for & .86 & 11.30 & \\
\hline It would be easy for me to leave this hotel (-) & .77 & 9.51 & \\
\hline I am tightly connected to this organization & .84 & 10.86 & \\
\hline
\end{tabular}


End of Table 1

\begin{tabular}{|c|c|c|c|}
\hline Scale items & $\begin{array}{l}\text { Standardized } \\
\text { loadings }\end{array}$ & $t$-value & $\mathrm{AVE}^{*}$ \\
\hline Service recovery performance & & & .57 \\
\hline $\begin{array}{l}\text { Considering all the things I do, I handle dissatisfied } \\
\text { customers quite well }\end{array}$ & $-^{* *}$ & - & \\
\hline I don't mind dealing with complaining customers & .70 & 7.76 & \\
\hline $\begin{array}{l}\text { No customer I deal with leaves with problems } \\
\text { unresolved }\end{array}$ & .81 & 9.52 & \\
\hline $\begin{array}{l}\text { Satisfying complaining customers is a great } \\
\text { thrill to me }\end{array}$ & $-^{* *}$ & - & \\
\hline $\begin{array}{l}\text { Complaining customers I have dealt with in the past } \\
\text { are among today's most loyal customers }\end{array}$ & .75 & 8.58 & \\
\hline Extra-role customer service & & & .74 \\
\hline $\begin{array}{l}\text { I voluntarily assist customers even if it means going } \\
\text { beyond job requirements }\end{array}$ & .87 & 11.41 & \\
\hline $\begin{array}{l}\text { I help customers with problems beyond what is } \\
\text { expected or required }\end{array}$ & .87 & 11.33 & \\
\hline $\begin{array}{l}\text { I often go above and beyond the call of duty when } \\
\text { serving customers }\end{array}$ & .78 & 9.51 & \\
\hline $\begin{array}{l}\text { I willingly go out of my way to make a customer } \\
\text { satisfied }\end{array}$ & .92 & 12.36 & \\
\hline I frequently go out the way to help a customer & .87 & 11.28 & \\
\hline
\end{tabular}

Model fit statistics: $\chi^{2}=554.01 ; \mathrm{df}=309 ; \chi^{2} / \mathrm{df}=1.79 ; \mathrm{CFI}=.92 ;$ IFI $=.92 ;$ RMSEA $=.085$; SRMR $=.053$.

Notes: Each item is measured on a five-point scale. All loadings are significant at the .01 level. CFI $=$ Comparative fit index; IFI = Incremental fit index; RMSEA = Root mean square error of approximation; SRMR = Standardized root mean square residual.

$(-)$ denotes reverse-scored item; ${ }^{*}$ Average variance extracted; ${ }^{* *}$ Items were dropped during confirmatory factor analysis

Table 2. Scale reliabilities, means, standard deviations, and correlations of study variables

\begin{tabular}{lcccccccccc}
\hline \multicolumn{1}{c}{ Variables } & Mean & SD & Alpha & 1 & 2 & 3 & 4 & 5 & 6 & 7 \\
\hline 1. Age & 2.06 & 1.13 & - & 1.000 & & & & & \\
\hline 2. Training & 3.12 & .86 & .92 & .031 & 1.000 & & & & \\
\hline 3. Empowerment & 2.93 & 1.04 & .94 & -.067 & $.482^{*}$ & 1.000 & & & \\
\hline 4. Rewards & 3.24 & .94 & .94 & .026 & $.602^{*}$ & $.434^{*}$ & 1.000 & & \\
\hline $\begin{array}{l}\text { 5. Job } \\
\text { embeddedness }\end{array}$ & 3.19 & .89 & .96 & $.277^{*}$ & $.538^{*}$ & $.461^{*}$ & $.605^{*}$ & 1.000 & \\
\hline
\end{tabular}


End of Table 2

\begin{tabular}{lcccccccccc}
\hline \multicolumn{1}{c}{ Variables } & Mean & SD & Alpha & 1 & 2 & 3 & 4 & 5 & 6 & 7 \\
\hline $\begin{array}{l}\text { 6. Service } \\
\text { recovery } \\
\text { performance }\end{array}$ & 3.51 & .69 & .79 & .011 & $.380^{*}$ & $.550^{*}$ & $.506^{*}$ & $.508^{*}$ & 1.000 & \\
\hline $\begin{array}{l}7 . \text { Extra-role } \\
\text { customer } \\
\text { service }\end{array}$ & 3.33 & .88 & .94 & .030 & $.506^{*}$ & $.457^{*}$ & $.382^{*}$ & $.436^{*}$ & $.609^{*}$ & 1.000 \\
\hline
\end{tabular}

Notes: Composite scores for each measure were obtained by averaging scores across items representing that measure. The scores for training, empowerment, rewards, job embeddedness, service recovery performance, and extra-role customer service from 1 to 5. Age was measured using a five-point scale. Higher scores demonstrated higher training, empowerment, rewards, job embeddedness, service recovery performance, extra-role customer service, and older age.

* Correlations are significant at the 0.01 level

\subsection{Test of research hypotheses}

The results pertaining to the effects of the indicators of management commitment to service quality on job embeddedness are presented in Table 3. As a control variable, age is significantly and positively related to job embeddedness. That is, older employees have high levels of job embeddedness. Training $(\beta=.19, p<.05)$, empowerment $(\beta=$ $.22, p<.01)$, and rewards $(\beta=.39, p<.001)$ are significantly and positively related to job embeddedness. Therefore, hypotheses 1(a), 1(b), and 1(c) are supported.

Table 3. Regression results: the effects of training, empowerment, and rewards on job embeddedness

\begin{tabular}{lcc}
\hline \multicolumn{4}{c}{ Dependent variable and standardized regression weights } \\
\hline \multicolumn{3}{c}{ Job embeddedness } \\
\hline Independent variables & Step 1 & Step 2 \\
\hline (I) Control variable & $.28^{* *}$ & $.28^{* * *}$ \\
\hline Age & & \\
\hline (II) Indicators of management commitment to service quality & & $.19^{*}$ \\
\hline Training & & $.22^{* *}$ \\
\hline Empowerment & $8.95^{* *}$ & $31.55^{* * *}$ \\
\hline Rewards & .07 & .51 \\
\hline$F$ & - & .44 \\
\hline$R^{2}$ at each step & & \\
\hline$\Delta R^{2}$ & & \\
\hline
\end{tabular}

Notes: Age was measured using a five-point scale. Higher scores demonstrated older age. The results regarding variance inflation factors did not demonstrate any problems of multicollinearity.

${ }^{*} p<.05,{ }^{* *} p<.01{ }^{* * *} p<.001$ 
The results in Table 4 demonstrate that training has a significant positive effect on extrarole customer service $(\beta=.34, p<.01)$. However, training is not significantly and positively related to service recovery performance. Therefore, hypothesis 2 (b) is supported, while 2(a) is not. The results show that empowerment significantly and positively influences service recovery performance $(\beta=.42, p<.001)$ and extra-role customer service $(\beta=.27, p<.01)$. Therefore, hypotheses 3(a) and 3(b) are supported. According to the results in Table 4 , rewards are significantly and positively related to service recovery performance $(\beta=.34, p<.01)$. Therefore, hypothesis $4(a)$ is supported. On the other hand, there is no empirical support for hypothesis 4(b), because rewards do not significantly and positively affect extra-role customer service.

The results regarding the effect of job embeddedness on service recovery performance and extra-role customer service and the mediating role of job embeddedness are also depicted in Table 4. According to the results in Table 4, job embeddedness significantly and positively influences service recovery performance $(\beta=.24, p<.05)$. Therefore, there is empirical support for hypothesis 5(a). However, the results show that job em-

Table 4. Regression results: job embeddedness as a partial mediator

\begin{tabular}{|c|c|c|c|c|c|c|c|}
\hline \multicolumn{8}{|c|}{ Dependent variables and standardized regression weights } \\
\hline \multirow[t]{2}{*}{$\begin{array}{l}\text { Independent } \\
\text { variables }\end{array}$} & \multicolumn{3}{|c|}{$\begin{array}{l}\text { Service recovery } \\
\text { performance }\end{array}$} & \multirow[t]{2}{*}{$\begin{array}{l}\text { Independent } \\
\text { variables }\end{array}$} & \multicolumn{3}{|c|}{$\begin{array}{l}\text { Extra-role customer } \\
\text { service }\end{array}$} \\
\hline & Step 1 & Step 2 & Step 3 & & Step 1 & Step 2 & Step 3 \\
\hline (I) Control variable & & & & (I) Control variable & & & \\
\hline Age & .01 & .03 & -.04 & Age & .03 & .04 & -.01 \\
\hline $\begin{array}{l}\text { (II) Indicators of } \\
\text { management } \\
\text { commitment } \\
\text { to service } \\
\text { quality }\end{array}$ & & & & $\begin{array}{l}\text { (II) Indicators of } \\
\text { management } \\
\text { commitment } \\
\text { to service } \\
\text { quality }\end{array}$ & & & \\
\hline Training & & -.03 & -.07 & Training & & $34^{* *}$ & $.31^{* *}$ \\
\hline Empowerment & & $.42^{* * *}$ & $.37^{* * *}$ & Empowerment & & $.27^{* *}$ & $.23^{*}$ \\
\hline Rewards & & $.34^{* *}$ & $25^{*}$ & Rewards & & .06 & -.01 \\
\hline $\begin{array}{l}\text { (III) Job } \\
\text { embeddedness }\end{array}$ & & & $.24^{*}$ & $\begin{array}{l}\text { (III) Job } \\
\text { embeddedness }\end{array}$ & & & .17 \\
\hline$F$ & .01 & $22.57^{* * *}$ & $4.99^{*}$ & $F$ & 1.00 & $16.32^{* * *}$ & 2.21 \\
\hline$R^{2}$ at each step & .00 & .39 & .42 & $R^{2}$ at each step & .00 & .32 & .33 \\
\hline$\Delta R^{2}$ & - & .39 & .03 & $\Delta R^{2}$ & - & .32 & .01 \\
\hline
\end{tabular}

Sobel test for:

Empowerment $\rightarrow$ Job embeddedness $\rightarrow$ Service recovery performance $1.74^{\dagger}$

Rewards $\rightarrow$ Job embeddedness $\rightarrow$ Service recovery performance $2.00^{*}$

Notes: Age was measured using a five-point scale. Higher scores demonstrated older age. The results regarding variance inflation factors did not demonstrate any problems of multicollinearity.

${ }^{\dagger} p<.10,{ }^{*} p<.05,{ }^{* *} p<.01{ }^{* * *} p<.001$ 
beddedness does not significantly affect extra-role customer service. Therefore, hypothesis 5(b) is not supported.

Hypotheses 6(a)-7(c) refer to the partial mediating role of job embeddedness. A close examination of the results in Table 4 indicates that when job embeddedness is entered in the equation, the magnitudes of the effects of empowerment $(\beta=.37, p<.001)$ and rewards $(\beta=.25, p<.05)$ on service recovery performance are reduced, but their effects remain significant. Sobel test result demonstrates that there is a significant mediating role of job embeddedness on the relationship between empowerment and service recovery performance $(t=1.74, p<.10)$. According to this result, this effect is marginally significant. Therefore, hypothesis $6(\mathrm{~b})$ receives partial support. Sobel test result also illustrates that there is a significant mediating role of job embeddedness on the relationship between rewards and service recovery performance $(t=2.00, p<.05)$. Therefore, hypothesis 6(c) is supported. However, hypothesis 6(a) is not supported since as a predictor variable, training is not significantly related to the mediator variable, which is job embeddedness.

As can be seen in Table 4, job embeddedness is not significantly linked to extra-role customer service. That is, it cannot mediate the effects of the indicators of management commitment to service quality on extra-role customer service. Therefore, hypotheses 7(a), 7(b), and 7(c) are not supported. The results remain intact with or without age in the model.

\section{Discussion}

This study developed and tested a conceptual model that examined the mediating role of job embeddedness on the relationship between the indicators of management commitment to service quality and performance outcomes. In the current study training, empowerment, and rewards were the three important indicators of management commitment to service quality while performance outcomes were service recovery performance and extra-role customer service. The hypothesized relationships were tested based on data collected from frontline hotel employees with a time lag of one week in Romania. The results reported in the present study provided empirical support for the majority of hypotheses. There are a number of observations associated with these results.

\subsection{Assessment of findings}

The results that training, empowerment, and rewards enhance frontline employees' job embeddedness are consonant with the study predictions. The results pertaining to the effects of training and rewards on job embeddedness also receive support from a recent empirical study (Bergiel et al. 2009). Service firms can retain a pool of frontline employees provided that they train them in terms of the requisite job and interpersonal skills on a continuous basis. This is also true for service firms, which regard their frontline employees as strategic partners and empower them for high quality service recovery performance. Such frontline employees can remain in the organization if their efforts regarding delivery of service quality and resolution of customers' complaints 
are rewarded. Consistent with internal fit, these HPWPs create synergy and help the organization to retain employees.

The result concerning the positive effect of empowerment on service recovery performance is in line with previous empirical studies (e.g. Ashill et al. 2004; Boshoff, Allen 2000; Yavas et al. 2003). The result that rewards increase frontline employees' service recovery performance is also consistent with other writings (Ashill et al. 2004; Boshoff, Allen 2000). It appears that empowerment and rewards are the important indicators of management commitment to service quality enhancing employees' service recovery performance. If such empowered employees know that they will be rewarded for service excellence, they are motivated to deal with customers' complaints by showing respect, effort, and empathy and thus have elevated levels of service recovery performance. Interestingly, the results do not lend any empirical support to the relationship between training and service recovery performance. The existing training programs among the hotels in Romania might have focused on development of technical skills. These programs might have overlooked listening and problem-solving skills, which are critical in providing effective responses to complaints. Under these circumstances, the presence of a training program with a concentration on development of technical skills does not necessarily influence employees' service recovery performance.

According to the results, training and empowerment increase extra-role customer service. These results suggest that the important role of discretionary behaviors for making customers satisfied might also have been taught to frontline employees in training programs associated with development of technical skills. Therefore, such employees display high levels of extra-role customer service behaviors. However, there is no empirical support for the relationship between rewards and extra-role customer service. It seems that frontline employees might have perceived the amount of rewards adequate for service recovery performance, but not for extra-role customer service. Overall, the results regarding the effects of training, empowerment, and rewards on service recovery performance and extra-role customer service appear to be partially consistent with the AMO model.

The results suggest that job embeddedness triggers frontline employees' service recovery performance. This is consonant with the precepts of job embeddedness theory and recent and past writings (Karatepe, Ngeche 2012; Lee et al. 2004). The links between the employee and others and the fit between the employee and the job increase the obligation and intrinsic motivation to have effective service recovery (cf. Halbesleben, Wheeler 2008). In addition, such employees should focus on delivery of service excellence and resolution of customers' complaints. Otherwise, they may lose their job as a result of poor service recovery. Contrary to the study expectation, job embeddedness is not significantly related to extra-role customer service. The presence of potential HPWPs in the organization might not be sufficient for employees to fit their job. Under these circumstances, employees do not display extra-role customer service behaviors. This can also be explained via social exchange theory (cf. Cropanzano, Mitchell 2005). Specifically, when employees find that they have inadequate resources from their organization, they do not feel obliged to show discretionary behaviors (cf. Saks 2006). 
As a result, they do not want to help organizations that have not provided sufficient resources for them (Lee et al. 2004).

Consistent with the study predictions, empowerment and rewards influence service recovery performance directly and indirectly via job embeddedness. The partial mediating role of job embeddedness on the relationship between empowerment and service recovery performance is not supported at the .05 level. However, such a finding is suggestive of a partial mediating role of job embeddedness and is an encouraging addition to limited research on job embeddedness in the services marketing literature. Overall the results suggest that empowered and rewarded employees are embedded in their job and display efforts necessary to restore the satisfaction of the aggrieved customer.

\subsection{Management implications}

The results of this study provide implications relevant for managerial practice. First, training, empowerment, and rewards are the indicators of management commitment to service quality enhancing job embeddedness. In addition, training, empowerment, and rewards increase employees' service recovery performance and/or extra-customer service. Although managements of many hotels state that service excellence is their top priority, they do not take decisive steps to invest in their frontline employees in terms of training, empowerment, and rewards. Since the quality of interaction between frontline employees and customers is a predictor of delivery of service quality and effective service recovery, managements of the hotels should ensure that there are continuous training programs focusing on development of employees' skills necessary to deliver technical and functional service quality and return disgruntled customers to a state of satisfaction after a service failure. It is also important that managements of the hotels should provide their employees with the adequate responsibility and authority for quick, appropriate, and equitable responses to dissatisfied customers and reward them based on their performance levels. However, it should be noted that empowerment may result in stress. Therefore, employees should be trained to accept the responsibility and authority in the workplace (Lashley 2000). Consequently, trained, empowered, and rewarded employees would not be interested in leaving the organization, because they are cognizant of costs emerging from such a behavior.

Second, hiring the right employees for frontline service jobs sends powerful signals to the existing employees pertaining to top management's commitment to service quality. During the hiring process managers can conduct structured interviews and customer service simulations to measure shared values (Maxham, Netemeyer 2003). This is important, since employees who do not share the organizational values will leave the organization or will not work at their full capacity for handling customers' complaints successfully. In closing, the aforementioned implications are also critical for the hotel industry in Romania. That is, due to the fact that the Romanian population is predicted to decline by $25 \%$ in the next 30 years (Ineson, Berechet 2011), managements of the hotels should retain a pool of employees who are embedded in their job and the organization. 


\subsection{Limitations and avenues for future research}

Though this study expands the current knowledge in the services marketing literature, there are several limitations, and viable prospects for future research remain. First, the present study used training, empowerment, and rewards as the three important and visible indicators of management commitment to service quality. Future research could include other potential indicators of management commitment to service quality or other potential HPWPs such as internal promotion opportunities, work-life balance, and teamwork for a better understanding of factors increasing frontline employees' job embeddedness (cf. Boselie et al. 2005). Second, Paauwe (2009) convincingly discusses that empirical research is needed regarding the relationships between past performance, human resource practices, and subsequent performance. In this study data were gathered from frontline hotel employees with a time lag of one week. Time-lagged designs appear to provide some evidence for temporal causality. However, it is not possible to make causal inferences conclusively (cf. Grandey, Cropanzano 1999). Therefore, future studies should investigate the relationships between past performance, management commitment to service quality, and subsequent performance over a longer period of time than it was done in this study.

Third, consistent with empirical studies in the relevant literature (e.g. Alexandrov et al. 2007; Mulki et al. 2008), the focus of this study was on the individual frontline employee as a unit of analysis. As argued by Wright and Nishii (2006), employees will show reactions on the basis of several internal strategies on the basis of their perceptions regarding the indicators of management commitment to service quality. The potential reactions are associated with individual differences. For example, core self-evaluations may moderate the effects of job embeddedness on service recovery performance and extra-role customer service. On the other hand, employees' perceptions of training, empowerment, and rewards as the indicators of management commitment to service quality may also vary according to the organizational and group levels (cf. Alexandrov et al. 2007). With this realization, in future research assessing individual differences as potential moderators of the relationships among the constructs depicted in this study and testing these relationships at the organizational and group levels via large sample sizes and adequate number of departments in each organization would be beneficial.

Fourth, this study collected data from frontline employees in a single country. In future studies testing the relationships demonstrated in the conceptual model using crossnational samples (e.g. Romania, Nigeria, China, and Turkey) would shed further light on the understanding of the mediating role of job embeddedness. Fifth, this study was employed in a single region of a single country. The sample of this study may not represent the whole frontline hotel employees in Romania. This may raise concerns about the representativeness of the study sample. As a potential remedy, in future studies obtaining data from frontline hotel employees in different regions in Romania would be beneficial. In closing, replication studies with large sample sizes in different service settings (for example, airlines, travel agencies, and banks) in Romania would be useful for broadening the database for further generalizations. 


\section{References}

Alexandrov, A.; Babakus, E.; Yavas, U. 2007. The effects of perceived management concern for frontline employees and customers on turnover intentions, Journal of Service Research 9(4): 356-371. http://dx.doi.org/10.1177/1094670507299378

Ashill, N. J.; Carruthers, J.; Rod, M. 2005. Antecedents and outcomes of service recovery performance in a public health-care environment, Journal of Services Marketing 19(5): 293-308. http://dx.doi.org/10.1108/08876040510609916

Ashill, N. J.; Krisjanous, J.; Carruthers, J. 2004. Antecedents and outcomes of service recovery performance in private and healthcare: an empirical investigation, International Review on Public and Non Profit Marketing 1(2): 57-74. http://dx.doi.org/10.1007/BF02896626

Ashill, N. J.; Rod, M.; Carruthers, J. 2008. The effect of management commitment to service quality on frontline employees' job attitudes, turnover intentions and service recovery performance in a new public management context, Journal of Strategic Marketing 16(5): 437-462. http://dx.doi.org/10.1080/09652540802480944

Babakus, E.; Yavas, U.; Karatepe, O. M. 2008. The effects of job demands, job resources and intrinsic motivation on emotional exhaustion and turnover intentions: a study in the Turkish hotel industry, International Journal of Hospitality and Tourism Administration 9(4): 384-404. http://dx.doi.org/10.1080/15256480802427339

Babakus, E.; Yavas, U.; Karatepe, O. M.; Avci, T. 2003. The effect of management commitment to service quality on employees' affective and performance outcomes, Journal of the Academy of Marketing Science 31(3): 272-286. http://dx.doi.org/10.1177/0092070303031003005

Banker, R.; Lee, S.-Y.; Potter, G.; Srinivasan, D. 1996. Contextual analysis of performance impacts of outcome-based incentive compensation, Academy of Management Journal 39(4): 920 948. http://dx.doi.org/10.2307/256717

Baron, R. M.; Kenny, D. A. 1986. The moderator-mediator variable distinction in social psychological research: conceptual, strategic, and statistical considerations, Journal of Personality and Social Psychology 51(6): 1173-1182. http://dx.doi.org/10.1037/0022-3514.51.6.1173

Bergiel, E. B.; Nguyen, V. Q.; Clenney, B. F.; Taylor, G. S. 2009. Human resource practices, job embeddedness and intention to quit, Management Research News 32(3): 205-219.

http://dx.doi.org/10.1108/01409170910943084

Bettencourt, L. A.; Brown, S. W. 1997. Contact employees: relationships among workplace fairness, job satisfaction and prosocial service behaviors, Journal of Retailing 73(1): 39-61.

http://dx.doi.org/10.1016/S0022-4359(97)90014-2

Boselie, P.; Dietz, G.; Boon, C. 2005. Commonalities and contradictions in HRM and performance research, Human Resource Management Journal 15(3): 67-94.

http://dx.doi.org/10.1111/j.1748-8583.2005.tb00154.x

Boshoff, C.; Allen, J. 2000. The influence of selected antecedents on frontline staff's perceptions of service recovery performance, International Journal of Service Industry Management 11(1): 63-90. http://dx.doi.org/10.1108/09564230010310295

Boxall, P.; Macky, K. 2009. Research and theory on high-performance work systems: progressing the high-involvement stream, Human Resource Management Journal 19(1): 3-23.

http://dx.doi.org/10.1111/j.1748-8583.2008.00082.x

Bowen, D. E.; Lawler, E. E. 1995. Empowering service employees, Sloan Management Review 36(Summer): 73-84.

Combs, J.; Liu, Y.; Hall, A.; Ketchen, D. 2006. How much do high-performance work practices matter? A meta-analysis of their effects on organizational performance, Personnel Psychology 59(3): 501-528. http://dx.doi.org/10.1111/j.1744-6570.2006.00045.x 
Cropanzano, R.; Mitchell, M. S. 2005. Social exchange theory: an interdisciplinary review, Journal of Management 31(6): 874-900. http://dx.doi.org/10.1177/0149206305279602

Crossley, C. D.; Bennett, R. J.; Jex, S. M.; Burnfield, J. L. 2007. Development of a global measure of job embeddedness and integration into a traditional model of voluntary turnover, Journal of Applied Psychology 92(4): 1031-1042. http://dx.doi.org/10.1037/0021-9010.92.4.1031

Davidow, M. 2003. Organizational responses to customer complaints: what works and what doesn't, Journal of Service Research 5(3): 225-250. http://dx.doi.org/10.1177/1094670502238917

De Jong, A.; De Ruyter, K. 2004. Adaptive versus proactive behavior in service recovery: the role of self-managing teams, Decision Sciences 35(3): 457-491.

http://dx.doi.org/10.1111/j.0011-7315.2004.02513.x

De Ruyter, K.; Wetzels, M. 2000. Customer equity considerations in service recovery: a crossindustry perspective, International Journal of Service Industry Management 11(1): 91-108.

http://dx.doi.org/10.1108/09564230010310303

Fornell, C.; Larcker, D. F. 1981. Evaluating structural equation models with unobservable variables and measurement error, Journal of Marketing Research 18(1): 39-50.

http://dx.doi.org/10.2307/3151312

Forrester, R. 2000. Empowerment: rejuvenating a potent idea, Academy of Management Executive 14(3): 67-80. http://dx.doi.org/10.5465/AME.2000.4468067

Gil, S. M.; Hudson, S.; Quintana, T. A. 2006. The influence of service recovery and loyalty on perceived service quality: a study of hotel customers in Spain, Journal of Hospitality and Leisure Marketing 14(2): 47-68. http://dx.doi.org/10.1300/J150v14n02_04

Grandey, A. A.; Cropanzano, R. 1999. The conservation of resources model applied to workfamily conflict and strain, Journal of Vocational Behavior 54(2): 350-370.

http://dx.doi.org/10.1006/jvbe.1998.1666

Guest, D.; Conway, N.; Dewe, P. 2004. Using sequential tree analysis to search for 'bundles' of HR practices, Human Resource Management Journal 14(1): 79-96.

http://dx.doi.org/10.1111/j.1748-8583.2004.tb00113.x

Haar, J. M. 2004. Work-family conflict and turnover intention: exploring the moderation effects of perceived work-family support, New Zealand Journal of Psychology 33(1): 35-39.

Halbesleben, J. R. B.; Wheeler, A. R. 2008. The relative roles of engagement and embeddedness in predicting job performance and intention to leave, Work and Stress 22(3): 242-256.

http://dx.doi.org/10.1080/02678370802383962

Han, H.; Back, K.-J. 2006. Investigating the effects of consumption emotions on customer satisfaction and repeat visit intentions in the lodging industry, Journal of Hospitality and Leisure Marketing 15(3): 5-30. http://dx.doi.org/10.1300/J150v15n03_02

Hartline, M. D.; Ferrell, O. C. 1996. The management of customer-contact service employees: an empirical investigation, Journal of Marketing 60(4): 52-70. http://dx.doi.org/10.2307/1251901

Hayes, B. E. 1994. How to measure empowerment, Quality Progress 27(February): 41-46.

Holtom, B. C.; Mitchell, T. R.; Lee, T. W. 2006. Increasing human and social capital by applying job embeddedness theory, Organizational Dynamics 35(4): 316-331.

http://dx.doi.org/10.1016/j.orgdyn.2006.08.007

Hoque, K. 1999. New approaches to HRM in the UK hotel industry, Human Resource Management Journal 9(2): 64-76. http://dx.doi.org/10.1111/j.1748-8583.1999.tb00197.x

Ineson, E. M.; Berechet, G. 2011. Employee loyalty in hotels: Romanian experience, Journal of Human Resources in Hospitality and Tourism 10(2): 129-149.

http://dx.doi.org/10.1080/15332845.2011.536694 
Joreskog, K.; Sorbom, D. 1996. LISREL 8: User’s Reference Guide. Chicago: Scientific Software International, Inc.

Karatepe, O. M.; Kilic, H.; Isiksel, B. 2008. An examination of the selected antecedents and outcomes of work-family conflict and family-work conflict in frontline service jobs, Services Marketing Quarterly 29(4): 1-24. http://dx.doi.org/10.1080/15332960802218620

Karatepe, O. M.; Ngeche, R. N. 2012. Does job embeddedness mediate the effect of work engagement on job outcomes? A study of hotel employees in Cameroon, Journal of Hospitality Marketing and Management 21(4): 440-461.

Karatepe, O. M.; Sokmen, A.; Yavas, U.; Babakus, U. 2010. Work-family conflict and burnout in frontline service jobs: direct, mediating and moderating effects, $E+M$ Ekonomie a Management 13(4): 61-73.

Kim, H. J.; Tavitiyaman, P.; Kim, W. G. 2009. The effect of management commitment to service on employee service behaviors: the mediating role of job satisfaction, Journal of Hospitality and Tourism Research 33(3): 369-390. http://dx.doi.org/10.1177/1096348009338530

Kusluvan, S.; Kusluvan, Z.; Ilhan, Z.; Buyruk, L. 2010. The human dimension: a review of human resources management issues in the tourism and hospitality industry, Cornell Hospitality Quarterly 51(2): 171-214. http://dx.doi.org/10.1177/1938965510362871

Lashley, C. 2000. Empowerment through involvement: a case study of TGI Fridays restaurants, Personnel Review 29(6): 791-815. http://dx.doi.org/10.1108/00483480010297211

Lee, T. W.; Mitchell, T. R.; Sablynski, C. J.; Burton, J. P.; Holtom, B. C. 2004. The effects of job embeddedness on organizational citizenship, job performance, volitional absences, and voluntary turnover, Academy of Management Journal 47(5): 711-722. http://dx.doi.org/10.2307/20159613 Lewis, B. R.; Gabrielsen, G. O. S. 1998. Intra-organizational aspects of service quality management: the employees' perspective, The Service Industries Journal 18(2): 64-89.

http://dx.doi.org/10.1080/02642069800000019

Marković, M. R. 2008. Managing the organizational change and culture in the age of globalization, Journal of Business Economics and Management 9(1): 3-11.

http://dx.doi.org/10.3846/1611-1699.2008.9.3-11

Maxham, J. G.; Netemeyer, R. G. 2003. Firms reap what they sow: the effects of shared values and perceived organizational justice on customers' evaluations of complaint handling, Journal of Marketing 67(1): 46-62. http://dx.doi.org/10.1509/jmkg.67.1.46.18591

Miller, D. G.; Madsen, S. R. 2003. The development of an instrument to address the negative perception of hospitality jobs: a pilot study, Journal of Human Resources in Hospitality and Tourism 2(2): 75-92. http://dx.doi.org/10.1300/J171v02n02_05

Min, H.; Min, H. 2005. The comparative evaluation of hotel service quality from a managerial perspective, Journal of Hospitality and Leisure Marketing 13(3/4): 53-77.

Mitchell, T. R.; Holtom, B. C.; Lee, T. W.; Sablynski, C. J.; Erez, M. 2001. Why people stay: using job embeddedness to predict voluntary turnover, Academy of Management Journal 44(6): 1102-1121. http://dx.doi.org/10.2307/3069391

Mulki, J. P.; Jaramillo, J. F.; Locander, W. B. 2008. Effect of ethical climate on turnover intention: linking attitudinal- and stress theory, Journal of Business Ethics 78(4): 559-574.

http://dx.doi.org/10.1007/s10551-007-9368-6

Paauwe, J. 2009. HRM and performance: achievements, methodological issues and prospects, Journal of Management Studies 46(1): 129-142.

http://dx.doi.org/10.1111/j.1467-6486.2008.00809.x 
Parameswaran, R.; Yaprak, A. 1987. A cross-national comparison of consumer research measures, Journal of International Business Studies 18(1): 35-49.

http://dx.doi.org/10.1057/palgrave.jibs.8490398

Pfeffer, J. 1994. Competitive Advantage through People: Unleashing the Power of the Work Force. Boston: HBS Press.

Podsakoff, P. M.; MacKenzie, S. B.; Lee, J. Y.; Podsakoff, N. P. 2003. Common method biases in behavioral research: a critical review of the literature and recommended remedies, Journal of Applied Psychology 88(5): 879-903. http://dx.doi.org/10.1037/0021-9010.88.5.879

Rees, C. J.; Althakhri, R. 2008. Organizational change strategies in the Arab region: a review of critical factors, Journal of Business Economics and Management 9(2): 123-132.

http://dx.doi.org/10.3846/1611-1699.2008.9.123-132

Saks, A. M. 2006. Antecedents and consequences of employee engagement, Journal of Managerial Psychology 21(7): 600-619. http://dx.doi.org/10.1108/02683940610690169

Schneider, B.; White, S. S.; Paul, M. C. 1998. Linking service climate and customer perceptions of service quality: test of a causal model, Journal of Applied Psychology 83(2): 150-163.

http://dx.doi.org/10.1037/0021-9010.83.2.150

Sekiguchi, T.; Burton, J. P.; Sablynski, C. J. 2008. The role of job embeddedness on employee performance: the interactive effects with leader-member exchange and organization-based self-esteem, Personnel Psychology 61(4): 761-792. http://dx.doi.org/10.1111/j.1744-6570.2008.00130.x

Singh, K. 2007. Predicting organizational commitment through organization culture: a study of automobile industry in India, Journal of Business Economics and Management 8(1): 29-37.

Solnet, D.; Hood, A. 2008. Generation Y as hospitality employees: framing a research agenda, Journal of Hospitality and Tourism Management 15: 59-68.

http://dx.doi.org/10.1375/jhtm.15.1.59

Wall, T. D.; Wood, S. J. 2005. The romance of human resource management and business performance, and the case for big science, Human Relations 58(4): 429-462.

http://dx.doi.org/10.1177/0018726705055032

Wright, P. M.; Nishii, L. H. 2006. Strategic HRM and organizational behavior: integrating multiple levels of analysis, CAHRS Working Paper Series. 405 p.

Yagil, D.; Luria, G.; Gal, I. 2008. Stressors and resources in customer service roles: exploring the relationship between core self-evaluations and burnout, International Journal of Service Industry Management 19(5): 575-595. http://dx.doi.org/10.1108/09564230810903479

Yao, X.; Lee, T. W.; Mitchell, T. R.; Burton, J. P.; Sablynski, C. S. 2004. Job embeddedness: current research and future directions, in Griffeth, R.; Hom, P. (Eds.). Understanding Employee Retention and Turnover. Greenwich, CT: Information Age, 153-187.

Yavas, U.; Karatepe, O. M.; Avci, T.; Tekinkus, M. 2003. Antecedents and outcomes of service recovery performance: an empirical study of frontline employees in Turkish banks, International Journal of Bank Marketing 21(5): 255-265. http://dx.doi.org/10.1108/02652320310488439

Yavas, U.; Karatepe, O. M.; Babakus, E. 2010. Relative efficacy of organizational support and personality traits in predicting service recovery and job performances: a study of frontline employees in Turkey, Tourism Review 65(3): 70-83. http://dx.doi.org/10.1108/16605371011083530 Yavas, U.; Karatepe, O. M.; Babakus, E.; Avci, T. 2004. Customer complaints and organizational responses: a study of hotel guests in Northern Cyprus, Journal of Hospitality and Leisure Marketing 11(2/3): 31-46. http://dx.doi.org/10.1300/J150v11n02_04

Zemke, 1991. Service recovery: a key to customer retention, Franchising World (May/June): $32-34$. 
Osman M. KARATEPE is Professor of Marketing in the Faculty of Tourism at Eastern Mediterranean University (Gazimagusa, TRNC, via Mersin 10, Turkey). His research interests are in the areas of services marketing and management, internal marketing, and international marketing. Among others, Dr. Karatepe has contributed to the Journal of the Academy of Marketing Science, Journal of Business Research, International Journal of Service Industry Management, The Service Industries Journal, Journal of Business Economics and Management, Managing Service Quality, Services Marketing Quarterly, Journal of Travel and Tourism Marketing, Journal of Hospitality Marketing and Management, International Journal of Bank Marketing, and Journal of Retailing and Consumer Services.

Georgiana KARADAS is a Ph.D. student and a research assistant in the Faculty of Tourism at Eastern Mediterranean University (Gazimagusa, TRNC, via Mersin 10, Turkey). Her research interests are in the areas of services marketing and human resource management. 